Original Research Paper

\title{
Penerapan Hasil Pengembangan Bahan Ajar Kimia Berbasis Masalah dengan Pendekatan Brain Based learning Untuk Penilaian Keterampilan Berpikir Kritis Dan Literasi Sains Peserta Didik di SMAN 4 Praya
}

\author{
Lalu Muhamad Ali Zakaria*1, Agus Abhi Purwoko², Saprizal Hadisaputra ${ }^{2}$ \\ ${ }^{1}$ Program Studi Magister Pendidikan IPA Universitas Mataram, Mataram. \\ ${ }^{2}$ Program Studi Pendidikan Kimia FKIPA Universitas Mataram, Mataram.
}

DOI: https://doi.org/10.29303/jpmpi.v3i2.566

Sitasi: Zakaria, L. M. A., Purwoko, A. A., \& Hadisaputra, S. (2021). Penerapan Hasil Pengembangan Bahan Ajar Kimia Berbasis Masalah dengan Pendekatan Brain Based learning Untuk Penilaian Keterampilan Berpikir Kritis Dan Literasi Sains Peserta Didik di SMAN 4 Praya. Jurnal Pengabdian Magister Pendidikan IPA, 4(1)

\section{Article history}

Received: 02 Desember 2020

Revised: 29 Desember 2020

Accepted: 13 Januari 2021

*Corresponding Auther: Lalu Muhamad Ali Zakaria, Program Studi Magister Pendidikan IPA Universitas Mataram, Mataram, Indonesia

Email:

laluzakaria707@gmail.com

\begin{abstract}
Artikel ini membahas tentang penerapan hasil pengembangan bahan ajar kimia berbasis masalah dengan pendekatan brain based learning untuk penilaian keterampilan berpikir kritis dan literasi sains. Penelitian ini dilakukan di SMAN 4 Praya. Pemilihan sampel dilakukan dengan teknik purposive sampling dengan jumlah sampel 34 siswa. Data dianalisis dengan persentase skor yang kemudian diinterpretasikan dengan kriteria kategori respon. Penilaian menggunakan dua pendekatan yaitu kualitatif dan kuantitatif. Hasil pendekatan kualitatif menunjukkan bahwa penerapan hasil pengembangan bahan ajar kimia berbasis masalah dengan pendekatan brain based learning menunjukkan kategori sangat positif dengan persentase di atas $80 \%$. Hasil pendekatan kuantitatif penilaian keterampilan berpikir kritis dan literasi sains juga menunjukkan kategori positif dengan persentase lebih dari $70 \%$. Sehingga penerapan hasil pengembangan bahan ajar kimia berbasis masalah dengan pendekatan brain based learning praktis digunakan untuk mengevaluasi keterampilan berpikir kritis dan literasi sains peserta didik SMAN 4 Praya
\end{abstract}

Keywords: Kepraktisan Bahan Ajar; Berbasis Masalah; Brain Based learning; Keterampilan Berfikir Kritis; Literasi Sains

\section{Pendahuluan}

Keterampilan berpikir kritis merupakan cara berpikir yang memberikan pertanyaan, percobaan, dan keyakinan terhadap pengetahuan yang diperoleh melalui percobaan (Susilowati et al, 2017). Berpikir kritis juga salah satu dari paradigma pembelajaran abad 21. Aspek abad 21 dalam pendidikan dapat menunjang dalam menghadapi tantangan abad 21 (Ramdani et al, 2019). Dalam menghadapi tantangan abad 21 juga diperlukan kemampuan untuk meliterasi pengetahuan terhadap fakta dan fenomena secara ilmiah.

Literasi sains merupakan kapasitas dalam penggunaan pengetahuan ilmiah, identifikasi pertanyaan, dan menarik kesimpulan berdasarkan fakta dan fenomena (OECD, 2018). Literasi sains menujang untuk mengkritisi dan mengimplementasikan hasil berpikir tersebut kedalam pengetahuan yang dimiliki. Dalam menarik minat peserta didik dalam berpikir kritis dan literasi sains diperlukan inovasi-inovasi dalam pembelajaran. Salah sartu caranya adalah dengan mengembangkan bahan ajar yang baik. 
Bahan ajar adalah bagian dari sumber belajar yang disusun sedemikian rupa dalam melaksanakan pembelajaran (Litaimer et al, 2019). Bahan ajar dijadikan sebagai pedoman pembelajaran khususnya pada pembelajaran kimia. Pedoman pembelajaran akan lebih baik jika dikembangkan dengan model atau pendekatan pembelajaran. Model atau pendekatan akan menjadi tolak ukur pelaksanaan pembelajaran agar lebih terarah dan terkonsentrasi sesuai dengan karakter peserta didik (Suryawati et al, 2017). Salah satu model yang cocok sesuai dengan tantangan abad ke- 21 dan literasi sains adalah dengan pembelajaran berbasis masalah.

Pembelajaran berbasis masalah merupakan pembelajaran yang menggunakan permasalahan dunia nyata dalam proses pembelajaran kimia (Baran et al, 2018). Pada prosesnya peserta didik diberikan suatu permasalahan yang kemudian peserta didik menyelesaikan dan mempersentasiskan suatu permasalahan yang mereka selesaikan tersebut . PBL digunakan sebagai model pembelajaran yang dapat meningkatkan kemampuan berpikir dan keterampilan dalam menyelesaikan suatu permasalahan pembelajaran kimia (Fahmidani et al, 2019). Kemampuan berpikir dan keterampilan akan lebih efektif jika dikombinasikan dengan pendekatan pembelajaran dalam meningkatkan kemampuan berpikir.

Salah satu pendekatan yang dapat meningkatkan kemampuan berpikir dalam pembelajaran kimia adalah brain based learning (BBL). BBL merupakan pendekatan yang menekankan pada penyeimbangan kemampuan otak (Sadiqin et al, 2017). BBL memberikan ketertarikan dan kesenangan dalam proses pembelajaran sehingga mampu memberikan latihan pada kemampuan berpikir dalam mengingat dan mengimplementasikan pembelajaran (Ulfa, 2020).

Hasil obeservasi melalui wawancara dengan tiga guru kimia di SMAN 4 Praya diperoleh bahwa bahan ajar atau perangkat pembelajaran yang diterapkan masih belum mampu melatih keterampilan berpikir kritis dan literasi kimia peserta didik. Hal ini dikarenakan masih banyak siswa yang pasif dan kurang berminat untuk belajar kimia. Sedangkan berdasarkan hasil observasi dan wawancara beberapa peserta didik menyatakan bahwa pelajaran kimia menjadi pelajaran yang tidak menarik dan dianggap sulit, dikarenakan banyak lambang, rumus, serta perhitungan yang menyulitkan dan harus dihafal sehingga membosankan bagi sebagian besar peserta didik.

Berdasarkan permasalahan hasil observasi dan wawancara dengan pendidik yang diperoleh maka tim peneliti tertarik untuk menerapkan hasil pengembangan bahan ajar kimia sebagai alat penilaian keterampilan berpikir kritis dan literasi sains peserta didik di SMAN 4 Praya. Penilaian dilakukan untuk menguji kepraktisan bahan ajar kimia yang telah dikembangakan dalam bentuk LKPD yang berbasis masalah dengan pendekatan brain based learning.

\section{Metode}

\section{a. Persiapan}

Persiapan yang dilakukan adalah dengan menyiapkan bahan ajar kimia yang meliputi bahan ajar dan Instrumen tes yang telah melalui tahap validitas. Bahan ajar kimia yang dikembangakan kemudian dilakukan implementasi pada 34 peserta didik kelas XI SMAN 4 Praya . Dalam penerapan bahan ajar kimia dilaksanakan sebanyak empat kali pertemuan. Pelaksanaan setiap pertemuan mengimplementasikan tiap pertemuan pada bahan ajar. Pada instrumen tes berjumlah 20 butir soal pilihan ganda dengan rincian 10 butir soal keterampilan berpikir kritis dan 10 butir soal literasi sains.

Tahap pertama yang dilakukan adalah dengan memberikan bahan ajar kimia kepada guru pengampu mata pelajaran untuk dianalisis dan diberikan penilaian menggunakan angket penilaian. Tahap kedua yaitu dilakukan uji coba. Uji coba tiap pertemuan dilaksanakan sesuai dengan bahan ajar kimia yang telah disusun pada setiap pertemuan. Pada setiap pertemuan dilakukan juga observasi keterlaksanaan pembelajaran oleh dua orang observer. Observasi yang dilakukan meliputi observasi pengelolaan pembelajaran oleh guru dan aktivitas yang dilakukan oleh peserta didik selama pembelajaran menggunakan bahan ajar kimia berbasis masalah dengan pendekatan brain based learning.

Tahap selanjutnya adalah memberikan angket penilaian peserta didik terhadap kegiatan 
pembelajaran yang telah dilakukan dan angket penilaian terhadap bahan ajar kimia yang digunakan dalam pembelajaran. Penilaian ini dilakukan untuk memperoleh tanggapan peserta didik terhadap bahan ajar kimia berbasis masalah dengan pendekatan brain based learning yang telah diimplementasikan kepada peserta didik. Pada tahap terakhir adalah tes keterampilan berpikir kritis dan literasi sains peserta didik.

b. Materi Bahan Ajar

Materi bahan ajar kimia yang dikembangkan untuk meningkatkan keterampilan berfikir kritis dan literasi sains peserta didik menggunakan materi kelarutan dan hasil kali kelarutan (Ksp) dalam bentuk LKPD dengan struktur materi konsep kelarutan, hubungan kelarutan dengan hasil kali kelarutan, pengaruh ion senama terhadap kelarutan, dan terbentuknya endapan berdasarkan pengaruh kelarutan.

Pada sub materi konsep kelarutan dilakukan identifikasi larutan tepat jenuh, larutan kelewat jenuh, dan larutan belum jenuh dengan melarutkan garam dengan jumlah yang berbeda pada pelarut yang sama. Pada sub materi hubungan kelarutan dengan hasil kali kelarutan (Ksp) mengidentifikasi larutan kemudian mengidentifikasi kelarutan berdasarkan harga Ksp standar. Pada sub materi pengaruh ion senama dilakukan identifikasi perbedaan kelarutan suatu larutan dengan pelarut air dan pelarut kation yang sama dengan zat terlarut. Sedangkan pada sub materi pembentukan endapan menafsirkan pembentukan endapan pelarut pada harga kelarutan dengan Ksp standar. Pengembangan bahan ajar kimia didesain dalam bentuk LKPD dengan karakteristik sesuai kompetensi dasar kurikulum 2013 (Tabel 1)

Tabel 1. Kompetensi Dasar pokok bahasan kelarutan dan hasil kali kelarutan

\begin{tabular}{ll}
\hline 3.14 & $\begin{array}{l}\text { Memprediksi terbentuknya endapan dari } \\
\text { suatu reaksi berdasarkan kesetimbangan } \\
\text { kelarutan dan data hasil kali kelaruta } \\
\text { Merancang dan melakukan percobaan } \\
\text { untuk memisahkan ion dalam larutan }\end{array}$ \\
\hline
\end{tabular}

c. Analisis hasil proses pembelajaran

Penilaian menggunakan dua pendekatan yaitu kualitatif dan kuantitatif. Data kualitatif menggambarkan keterlaksanaan proses yang bersunber dari observer, respon guru, dan respon peserta didik dalam bentuk angket. Sementara itu, data kuantitatif menggambarkan nilai skor tes keterampilan berpikir kritis dan literasi sains peserta didik. Proses selanjutnya adalah melakukan analisi dengan menggunakan persamaan persentase skor (Sugiono, 2017). Persamaan persentase skor dapat dilihat pada persamaan berikut:

$$
\% \text { skor }=\frac{\text { skor dari responden }}{\text { skor maksimal }} \times 100 \%
$$

Hasil analisis selanjutnya dilakukan interpretasi berdasarkan kategori (Tabel 2)

Tabel 2. Kategori Kriteria Respon

\begin{tabular}{|c|c|c|}
\hline $\begin{array}{l}\text { Persentase } \\
(\%)\end{array}$ & Respon & Kategori Respon \\
\hline $0-20$ & & Sangat Tidak \\
\hline $21-40$ & & Positif \\
\hline $41-60$ & & Kurang Positif \\
\hline $61-80$ & & Cukup Positif \\
\hline \multirow[t]{2}{*}{$81-100$} & & Positif \\
\hline & & Sangat Positif \\
\hline
\end{tabular}

\section{Hasil dan Pembahasan}

Pada penelitian ini dilakukan dua buah pengujian penerapan bahan ajar kimia berbasis masalah dengan pendekatan brain based learning sebagai penilaian keterampilan berpikir kritis dan literasi sains. Pengujian pertama adalah pengujian hasil penerapan bahan ajar kimia berdasarkan penilaian bahan ajar kimia berbasis masalah berdasarkan hasil respon dan pengujian yang kedua adalah pengujian hasil penerapan instrumen evaluasi pada peserta didik. Untuk hasil pengujiannya sebagai berikut:

a. Penerapan bahan ajar kimia

Data hasil penerapan bahan ajar kimia yang diperoleh dari keterlaksanaan proses pembelajaran, respon guru dan pendidik terhadap bahan ajar dapat dilihat pada tabel 3 . 
Tabel 3 Hasil penerapan pengembangan bahan ajar kimia

\begin{tabular}{|c|c|c|c|}
\hline NO & $\begin{array}{l}\text { Data Uji Coba } \\
\text { Terbatas }\end{array}$ & $\begin{array}{l}\text { Rata- } \\
\text { rata }\end{array}$ & Kriteria \\
\hline 1 & $\begin{array}{l}\text { Keterlaksanaan } \\
\text { proses } \\
\text { pembelajaran }\end{array}$ & $88,6 \%$ & $\begin{array}{l}\text { Sangat } \\
\text { Positif }\end{array}$ \\
\hline 2 & $\begin{array}{l}\text { Respon guru } \\
\text { terhadap } \\
\text { ajar }\end{array}$ & $80,87 \%$ & $\begin{array}{l}\text { Sangat } \\
\text { Positif }\end{array}$ \\
\hline 3 & $\begin{array}{l}\text { Respon peserta } \\
\text { didik terhadap } \\
\text { bahan ajar }\end{array}$ & $89,7 \%$ & $\begin{array}{l}\text { Sangat } \\
\text { Positif }\end{array}$ \\
\hline
\end{tabular}

Berdasarkan tabel 3 menunjukkan bahwa kertelaksanaan proses pembelajaran dengan penerapan bahan ajar yang dikembangkan sebesar $88,6 \%$ dengan kategori sangat positif, respon guru maupun peserta didik terhadap penerapan bahan ajar kimia yang dikembangkan juga memperoleh skor rata-rata $80,87 \%$ dan $89,7 \%$ dengan kategori sangat positif. Hal ini menunjukkan bahwa bahan ajar kimia berbasis masalah dengan pendekatan brain based learning pada materi kelarutan dan hasil kali kelarutan (Ksp) dikembangkan praktis digunakan dalam pembelajaran kimia di SMAN 4 Praya. Hal ini sejalan dengan penelitian Mukmin at al (2018) menyatakan bahwa kepraktisan suatu bahan ajar atau perangkat pembelajaran dengan kategori postif praktis digunakan dalam pembelajaran. Laksmiwati et al (2019) juga menambahkan bahan ajar berbasis masalah praktis digunakan dalam pembelajaran sains. Pendapat lain juga menambahkan pembelajaran berbasis masalah dan pendekatan yang melatih kemampuan berpikir praktis digunakan untuk keterampilan berpikir kritis dan literasi sains peserta didik ( $\mathrm{Al}$ Idrus et al, 2020)

\section{b. Penerapan evaluasi}

Penerapan evaluasi digunakan untuk menganalisis keterampilan berpikir kritis dan literasi sains peserta didik setelah menggunakan bahan ajar kimia berbasis masalah dengan pendekatan brain based learning. Data hasil evaluasi kepraktisan tiap indikator pada kemampuan berpikir kritis dan literasi sains diperoleh dari hasil skor yang diperoleh dari peserta didik uji coba terbatas. Hal ini bertujuan untuk memperoleh ketercapaian tiap indikator pada uji coba kepraktisan. Hasilnya dapat dilihat pada tabel berikut ini yaitu tabel 4 .

Tabel 4 Hasil evaluasi indikator keterampilan berfikir kritis dan literasi sains

\begin{tabular}{cccc}
\hline Evaluasi & Indikator & Persentase & $\begin{array}{c}\text { Rata- } \\
\text { rata }\end{array}$ \\
\hline Berfikir & IBK-1 & 76,5 & \\
Kritis & IBK-2 & 77,9 & \\
& IBK-3 & 73,5 & $74,94 \%$ \\
& IBK-4 & 79,4 & \\
Literasi & IBK-5 & 67,6 & \\
Sains & ILS-1 & 80,9 & \\
& ILS-2 & 78,4 & $75 \%$ \\
\hline
\end{tabular}

Tabel 4 menunjukkan bahwa setiap indikator soal memiliki persentase indikator pada setiap indikator berpikir kritis dan literasi sains ratarata sebesar $74,98 \%$ dan $75 \%$. Hal ini menunjukkan bahwa tiap indikator pada soal memberikan persentase kemampuan berpikir kritis dan literasi sains > 70\%. Hal ini menunjukkan bahwa kepraktisan tiap indikator tergolong praktis untuk mengukur keterampilan berpikir kritis dan literasi sains peserta didik di SMAN 4 Praya. Sejalan dengan hasil penelitian Hasana et al (2017) yang menyatakan bahwa instrumen evaluasi yang memiliki kriteria positif praktis digunakan dalam mengevaluasi literasi sains peserta didik. Pendapat lain juga menegaskan bahwa instrumen evaluasi praktis digunakan untuk mengukur keterampilan berpikir kritis dan literasi sains setelah memenuhi kritieria positif dengan nilai lebih besar dari $70 \%$ (Sutiyoningtyas et al, 2020).

c. Kegiatan Pelaksanaan penerapan bahan ajar

Pelaksanaan penerapan bahan ajar kimia yang telah dikembangkan meliputi tahapan-tahapan sesuai dengan kurikulum 2013 dengan menggunakan pembelajaran sistem luring. Tahapannya meliputi kegiatan awal, kegiatan inti, kegiatan penutup, dan pada akhir pembelajaran dilakukan evaluasi. Tahapantahapan kegiatan pembelajaran menggunakan bahan ajar kimia berbasis masalah dengan 
pendekatan brain based learning dapat dilihat pada gambar berikut.

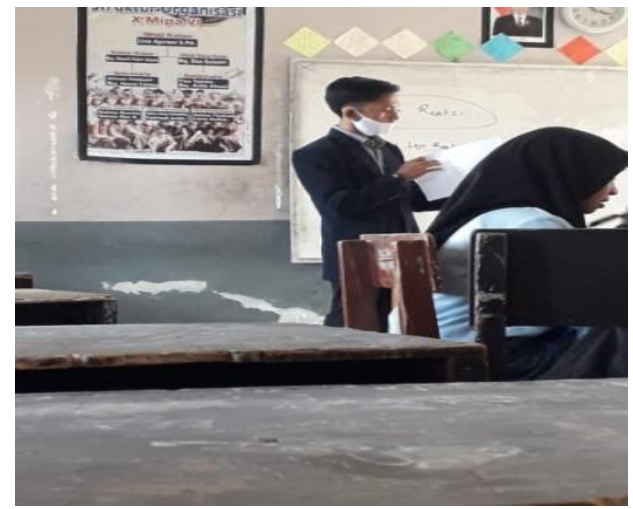

Gambar 1. Kegiatan Awal

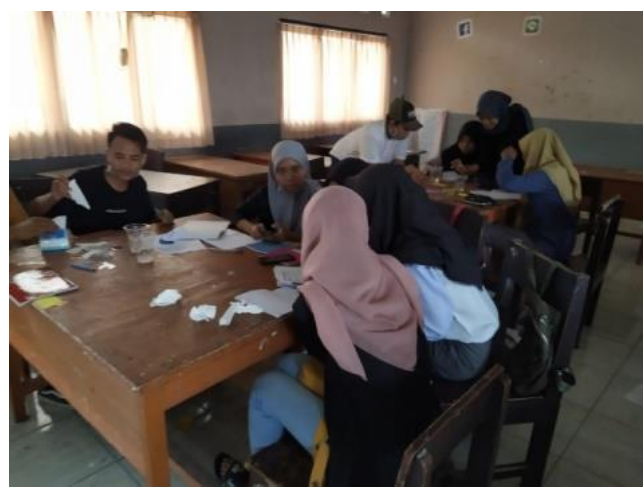

Gambar 2. Kegiatan Inti

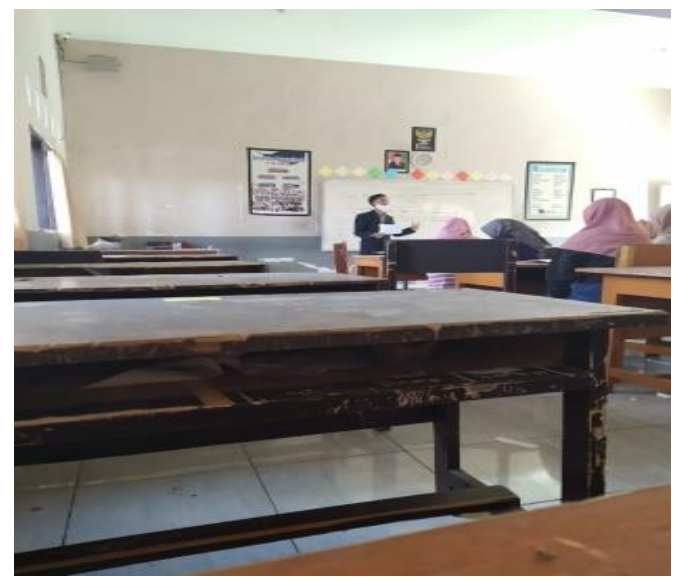

Gambar 3. Kegiatan Penutup

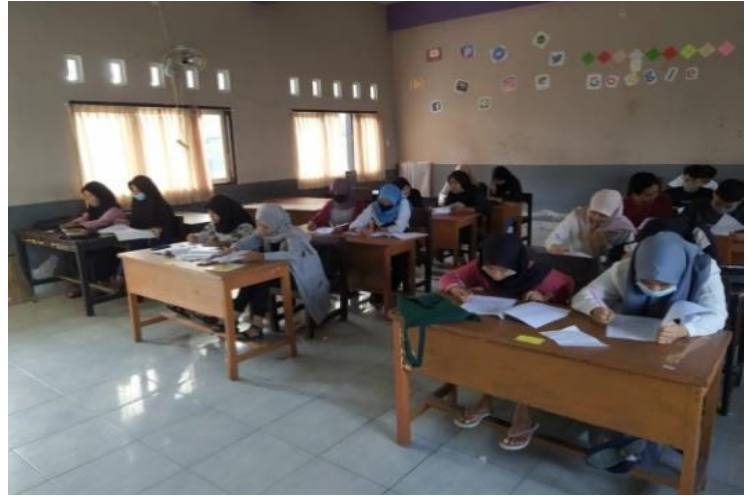

Gambar 4. Penerapan evaluasi

Berdasarkan gambar-gambar di atas mengilustrasikan penerapan bahan ajar kimia yang dikembangkan dalam proses pembelajaran kimia pada materi kelarutan dan hasil kali kelarutan. Pada kegiatan awal dipaparkan penggunaan bahan ajar kimia dalam bentuk lembar kerja (LKPD) yang akan dilakukan oleh peserta didik. Pada gambar 2 diilustrasikan kegiatan penggunaan bahan ajar kimia yang dikembangkan oleh peserta didik. Pada gambar 3 diilustrasikan akhir dari pembelajaran pada tiap pertemuan. Sedangkan pada gambar 4 mengilustrasikan penggunaan instrumen evaluasi keterampilan berfikir kritis dan literasi sains peserta didik kelas XI MIPA 3 di SMAN 4 Praya.

\section{Kesimpulan}

Berdasarkan hasil analisis dan pembahasan maka dapat disimpulkan bahwa

a. Bahan ajar pada materi kelarutan dan hasil kali kelarutan berbasis masalah dengan pendekatan brain based learning praktis untuk digunakan dalam pembelajaran kimia di SMAN 4 Praya dengan kategori sangat positif berdasarkan keterlaksanaan pembelajaran, respon pendidik dan peserta didik.

b. Setiap indikator evaluasi pada penerapan bahan ajar kimia menunjukkan kategori positif untuk digunakan dalam evaluasi keterampilan berpikir kritis dan literasi sains peserta didik di SMAN 4 Praya. 


\section{Ucapan Terima Kasih}

Penelitian ini didanai oleh Direktorat Riset dan Pengabdian Masyarakat, Deputi Bidang Penguatan Riset dan Pengembangan, Kementrian Riset, Teknologi/Badan Riset dan Inovasi Nasional Sesuai dengan Kontrak Penelitian Tahun Anggaran 2020 Nomor: 047/SP2H/LT/DRPM/2020

\section{Daftar Pustaka}

Al Idrus, S. W., Purwoko, A. A., Hadisaputra, S., \& Junaidi, E. (2020). Pengembangan Modul Praktikum Kimia Lingkungan Berbasis Green Chemistry Pada Mata Kuliah Kimia Lngkungan. Jurnal Pijar Mipa, 15(5), 541-547.

Arikunto, S. (2010). Prosedur Penelitian (Suatu Pendekatan Praktik). Yogyakarta: Rineka Cipta.

Baran, M., \& Sozbilir, M. (2018). An Application of Context-and Problem-Based Learning (C-PBL) into Teaching Thermodynamics. Research in Science Education, 48(4), 663-689.

Fahmidani, Y., Andayani, Y., Srikandijana, J., \& Purwoko, A. A. (2019). Pengaruh Model Pembelajaran Berbasis Masalah dengan Media Lembar Kerja Terhadap Hasil Belajar Siswa SMA. Chemistry Education Practice, 2(1), 1-5.

Hasana, I., Saptasari, M., \& Wulandari, N. (2017). Pengembangan Instrumen Penilaian Kemampuan Literasi Sains Siswa Kelas XI Materi Sistem Ekskresi Dan Koordinasi di SMAN 9 Malang. Jurnal Pendidikan Biologi, 8(2), 52-56.

Laksmiwati, D., Hadisaputra, S., \& Siahaan, J. (2019). Pengembangan Modul Praktikum Kimia Berbasis Problem Based Learning Untuk Kelas XI SMA. Chemistry Education Practice, 1(2), 36-41.

Litaimer, D., \& Putra, I. E. D. (2019). Penggunaan Sumber Belajar Diktat Buatan Guru Pada Pembelajaran Seni Budaya Di Mts Padang Laweh Kabupaten Sijunjung. Jurnal Sendratasik, 7(4), 61-67.

Mukmin, B. A., \& Zunaidah, F. N. (2018). Pengembangan Bahan Ajar DELIKAN Tematik Berbasis Multimedia Interaktif Untuk Siswa Sekolah Dasar di Kota
Kediri. Al Ibtida: Jurnal Pendidikan Guru MI, 5(2), 145-158.

OECD-pisa.2018. Assessment and Analytical Framework Science, Reading, Matematic and Financial Literacy.Paris: OECD.

Ramdani, A., Jufri, A. W., Gunawan, G., Hadisaputra, S., \& Zulkifli, L. (2019). Pengembangan Alat Evaluasi Pembelajaran IPA Yang Mendukung Keterampilan Abad 21. JPPIPA (Jurnal Penelitian Pendidikan IPA), 5(1), 98-108.

Sadiqin, I. K., Istyadji, M., \& Winarti, A. (2017). Mengoptimalkan Potensi Otak Kanan Siswa dalam Pembelajaran Kimia. Quantum: Jurnal Inovasi Pendidikan Sains, 8(1), 27-35.

Setiyoningtyas, R., \& Kasmui, K. (2020). Pengembangan Quizizz-Assisted Test Berbasis Literasi Peserta Didik Pada Materi Larutan Elektrolit Nonelektrolit. Chemistry in Education, 9(2), 63-69.

Sugiono. (2017). Metode Penelitian \& Pengembangan: Research and Development. Yogyakarta: Alfabeta Bandung.

Suryawati, E., \& Osman, K. (2017). Contextual learning: Innovative approach towards the development of students' scientific attitude and natural science performance. Eurasia Journal of Mathematics, Science and Technology Education, 14(1), 61-76.

Susilowati, S., \& Ramli, M. (2017). Analisis Keterampilan Berpikir Kritis Siswa Madrasah Aliyah Negeri di Kabupaten Magetan. In Seminar Nasional Pendidikan Sains, 21(1), 223-231.

Ulfa, F. K. (2020). Kemampuan Koneksi Matematis dan Berpikir Kritis Siswa Dalam Pembelajaran Matematika Melalui Model Brain-Based Learning. Jurnal Pendidikan Matematika (JPM), 6(2), 10611 